\title{
The Extent of Practicing Social Interaction Skills by Jordanian Elementary School Students in accordance with Carl Orff's Approach to Music Education
}

\author{
Tariq William Odeh ${ }^{1} \&$ Mohammad Saleem Al Zboon ${ }^{2}$ \\ ${ }^{1} \mathrm{PhD}$ student in Educational Foundations, Faculty of Educational Sciences, University of Jordan, Amman, \\ Jordan \\ ${ }^{2}$ Prof. in Educational Foundations, Faculty of Educational Sciences, University of Jordan, Amman, Jordan \\ Correspondence: Mohammad Saleem Al Zboon, Prof. in Educational Foundations, Faculty of Educational \\ Sciences, University of Jordan, Amman, Jordan. E-mail: drzboon@yahoo.com
}

Received: December 24, 2017

Accepted: February 10, 2018

Online Published: February 27, 2018

doi:10.5539/mas.v12n3p95

URL: https://doi.org/10.5539/mas.v12n3p95

\begin{abstract}
The present study aimed at identifying the extent of practicing social interaction skills by Jordanian elementary school students in accordance with Carl Orff's approach to music education. The study's population consists from all the male and female music teachers who teach at primary levels in public and private Jordanian schools (i.e. 350 female and male teachers). In order to collect the required data, the researchers developed a questionnaire that consists from 50 statements.

It was concluded that the level of practicing the social interaction skills by Jordanian elementary school students is low from the perspective of the sampled teachers. That is because the total arithmetic mean is 1.80 . As for the total standard deviation, it is 0.71 . In addition, the means of all the questionnaire statements are within the moderate and low levels. In the light of the study's results, the researchers recommend the following:

1. Promoting the role of the music education at private and public schools. The researchers also recommend providing all the necessary means and instruments for facilitating and improving the educational process

2. Holding more training courses for teachers regularly by the ministry of education about the music education strategies and methods.
\end{abstract}

Keywords: social interaction skills, Jordanian elementary school students

\section{Introduction}

The educational process aims at achieving social integration through turning human beings from biological beings into social beings. They are turned so through promoting interaction between them and the elements of the environment surrounding them. Based on the aforementioned, social interaction has become one of the pillars of the development and formation of the social characteristics of one's personality. In addition, social interaction is also considered a fundamental mean for learning and coping. It is also a fundamental tool for organizing societies and communities and passing their cultures from one generation to another (Naser, 2004).

It should be noted that all school subjects participate in achieving these goals and functions. One of those subjects is the music subject which contributes as much as the other subjects in achieving these goals and functions. For instance, musical education participates in developing the learner's personality through unleashing his potentials and fulfilling his latent needs that are associated with the development stage he is going through. According to psychology, one's personality consists from permanent physical and psychological tendencies that distinguish one from others. One's personality also consists from several components that concern physical, mental, emotive and social aspects. These components are not separate from one another. In fact, they interact with one another and complement and affect each other. In other words, the structure of one's personality is considered complex and involve a variety of aspects and characteristics. Thus, music education should focus on all the personality's aspects without excluding any, rather than focusing on one aspect only.

It should be noted that using the appropriate music educational methods shall participate in developing one's 
personality fully in all its aspects. That shall enable one to cope with his social and physical environments and achieve harmony between one's self and these environments (Sadeq, 2007).

Music education involves various activities that can participate in developing one physically. For instance, it participate in developing one's hearing sense. That is achieved through training one to distinguish between different auditory stimuli and describe them. Such stimuli may include the sounds of the surrounding nature. As for their description, it may involve their pitch, thickness, duration and aspects of similarities and differences with other sounds.

Music education improves motor coordination and muscle synergies leading to achieve physical coordination. Such education also makes the learners acquire several motor skills that have mental and social aspects. However, the physical and muscular aspects dominate these skills. One can acquire such skills when practicing music activities, such as: singing, doing rhythmic exercises, and playing musical instruments (Al-Wahsh, 2014).

From an emotive perspective, efficient music education participates in developing positive artistic inclinations that play a significant role in improving the learner's behavior. Such inclinations improve one's ability to control his various emotional responses and reduce stress and anxiety levels leading to achieve a balance. These inclinations also stimulate positive emotional responses, such as: joy, delight and sympathy. That shall lead in turn to increase the learner's motivation to express himself (Ezz, 2011).

From a social perspective, practicing group music education activities shall increase the learner's social maturity and awareness. It shall encourage the formation of social groups that share common goals and orientations. It shall also promote a sense of initiative and responsibility within the learner when performing his musical role. Practicing such activities shall make the learners acquire social behavior patterns related to the human relationships existing between the group members. Such patterns may include: respect, cooperation, understanding, commitment, and self-control. Acquiring these patterns shall increase the learner's social discipline. Furthermore, music education plays a significant social role represented in passing the cultural heritage and the aesthetic aspects of the society from one generation to another. That shall be positively reflected on the social interaction between the members of the music group (Sadeq, 2007).

One of the contemporary and modern approaches to music educationist Carl Orff's approach. Through the latter approach, Orff provides philosophical ideas that participated in setting the music education foundations. The latter composer believes that music is the closest kind of art to the child and the thing that the child loves the most. He also believes that music is the thing that influence the child the most. That is because it is the mean that the child uses to express himself freely without constrains (Al-Hares, 2010).

Orff's music education ideas emphasizes the principle of (learning through playing). Applying this principle shall turn children's non-structured playing and singing into structured ones that have specific goals. Such goals may include stimulating their imagination, improving their areas of creativity and making use of their latent movement energy in an early age. Orff's music education ideas focus much on popular folk songs, children's songs, tales, stories, and games involving rhythmic exercises. All of these are connected to the child's social environment and needs.

One of the pillars of Carl Orff's approach to music education is represented in engaging the child in music experiences on the sensual and practical levels in a non-structured manner before making these experiences governed by rules and theories. That is similar to the process of learning how to read and write. For instance, at the beginning, the child learns the alphabets, then he identifies the theory by himself through deductive reasoning under his teacher's directions. That is implemented to avoid making the educational process a boring and dull process. Adopting this method shall develop the child's self-expression skills, self-efficacy, and self-awareness leading to improve his social competence, including the social interaction skills (Al-Lou, 2008).

The concept (self-expression) refers to a group of procedures through which people can express their rights, desires, inclinations, and attitudes or their opinions and feelings without violating the rights of others. It is also defined as the process that one carries out to develop his self-trust and establish relationships with others and the ability to maintain these relationships and make new ones. As for self-efficacy, it is defined as being one's belief of being capable to perform a specific task. Social skills are developed through allowing new relationships to develop, provided that such relationships involve interaction with a group of people (Yun and Kim, 2013).

School is a significant educational institution that complements the family's role. The child spends most of his time at it and it affects the formation and development of all his personality's aspects. It also affects his habits, activities, behaviors on the physical, psychological, mental, social, affective and congenital levels. If the school's educational environment is appropriate, it shall positively affect the students. It should be noted that all school 
subjects - including music - participate in developing all the aspects of the student's personality. Thus, the music subject must be provided with adequate attention to promote its role in way that shall be reflected positively on the students' personality and the whole society.

Eric (2002) aimed at reviewing the studies that concern the relationship between music and emotive intelligence (EI). The latter researcher adopted the descriptive approach. He concluded that music has a positive impact on the functions of the brain cells responsible for emotive intelligence and mood. He also concluded that music increases motivation, and enhances one's cultural and artistic awareness. It can also improve one's awareness about aesthetics related matters. It was concluded that music can develop one's self-awareness skills and enable one to achieve self-realization and understand other people's feelings. Thus, music can enhance one's ability to integrate socially within the group and the surrounding community. It was concluded that it shall positively affect the development of one's emotional and social intelligence

Long et al. (2013) aimed at testing Carl Orff's approach among the primary school students enrolled in the public and private schools at the state of Illinois at the United States of America (USA). Their sample consists from 46 female and male students who were chosen from Marshall Primary School from two different grades. To be specific, 21 female and male third grade students were taught in groups through using Orff's approach and performing music activities. They were divided into 4 groups and asked to perform each activity in turn. In addition, the latter researchers selected 25 female and male sixth grade students and the second lesson was illustrated to them. That was done through adopting the same procedures that were adopted when teaching the third grade students. The teacher illustrated to the students the practices they should perform while singing with music. Such practices include using body language. The latter researchers observed the way students learn when engaging them in music activities that are based on Orff's approach. The study was conducted with the cooperation of female and male teachers working at the school. In addition, lessons were recorded through using a camera video in order to record the observed data on papers and analyze them later. A questionnaire was also developed. The questionnaire forms were distributed to students after the experiment was finished. It was concluded that students responded positively to the music activities that are designed through Orff's approach.

Yun and Kim et al. (2013) aimed at identifying the effectiveness of Orff's approach in improving the self-expression, and social skills, and self-efficacy of the children who belong to families of low income in South Korea. That was done through adopting the experimental approach. The population of the latter study consists from all the children who belong to families of low income in South Korea. The latter researchers selected a random sample that consists from 43 children. These children belong to families whose monthly income is below average in South Korea according to their social security law. The experimental group was taught through using the Orff's approach, whereas the control group was taught through using the traditional method. It was concluded that the self-expression, and social skills, and self-efficacy levels were significantly improved among the members of the experimental group in comparison to the control group. It was concluded that it is necessary to apply Orff's approach to develop the emotional, and physiological aspect of the personality among the children who suffer from poverty. It was also concluded that it is necessary to useOrff's approach instead of the traditional methods. That is because Orff's approach is appropriate and takes into consideration the developmental needs of children on the biological, psychological, and physiological levels.

Jasem (2013) aimed at identifying the impact of a music-based training program on the development off avorable social behaviors among the nursery children. The purposive sample of the latter study consists from 200 female and male nursery children. They were selected from various nurseries that are affiliated with Baghdad directorates of education at Iraq. The sample was divided into two groups; a female group and a male group. The female group consists from 100 children and the male group consists from 100 children. She conducted the study through adopting the experimental approach. She used a social behavior scale. 24 female and male children received low scores. After that, they were divided into control and experimental groups. Each group includes 12 children. A test was conducted to identify how equivalent their levels are. Then, a training program was developed. This program includes a variety of music activities. This program was applied to the members of the experimental group. The pre-test and post-test forms were distributed to the sample. It was concluded that there are statistically significant differences between the post-test scores of the experimental and control groups for the favor of the experimental group and attributed to the music-based training program.

Webster (2015) aimed at identifying the impact of teaching music on the academic, social and emotional outcome of students from the perspective of secondary school students and their parents. The sample was selected from the schools and institutes that are affiliated with the directorates of education at Texas State. The sample was selected in way that represents the study's population. The study was conducted in cooperation with the Texas Music Educators Association (TMEA). The sample consists from 15 male and female individuals who 
are students and parents. To be more specific, the sample consists from 4 male students, and 4 female students who are secondary school students. The sample also includes 7 mothers and 2 fathers. The respondents were examined through the magnetic resonance imaging (MRI) method to measure the activity of their brain cells. That was conducted to identify all the variable that might affect blood flow speed. In order to check the reliability of the overall student's academic score, IQ scores were measured.

Non-verbal Raven's progressive matrices (RPM) test was conducted to measure the advanced progressive matrices among the learners. This test is widely used because it suits children of all ages. In addition, the Torrance test of creative thinking (TTCT) and face to face interviews were conducted. Through these interviews, the researcher asked the sample close ended questions that involve academic, social and emotional areas. In addition, the interviews were recorded through audio records. These records include the respondents' answers to the questions that involve the academic, social and emotional areas. The collected data was recorded on papers and analyzed. It was concluded that participants confirmed that engaging in a variety of music education activities and experiences has a significant positive impact on academic outcomes, or results. Such academic outcomes involve: (neuro plasticity, behavioral changes, thinking patterns, remembering, problem solving, decision making, and decoding). It was also concluded that engaging in such activities and experiences has a significant positive impact on social outcomes. Such social outcomes involve: self-expression, self-confidence, communication, leadership skills, and accepting and recognizing others. Such social outcomes also involve participation, interaction and mutual trust among the group member. It was also concluded that engaging in such activities and experiences has a significant positive impact on emotional and affective outcomes, such as: mental health stability, empathy, fulfillment of one's needs and unleashing one's potentials. The latter outcomes also involve caring about others' feelings and appreciating one's feelings by one's self.

Based on the aforementioned studies, it can be concluded that researchers are concerned with investigating the actual music education practices carried by teachers and students. That is done to achieve a deeper understanding that shall enable these researchers to suggest appropriate solutions for the problems faced in the music education process. That is done in the aim of promoting the role of music education. The aforementioned studies provide a review for the relevant theoretical studies that cover various areas and aspects. The results of these studies vary due to the variation between them in terms of variables, samples, programs, objectives, circumstances, spatial dimensions and environments. The researchers of the present study provide a review for the aforementioned studies to develop and support the theoretical framework of the present study.

\section{Statement of the Problem}

After reviewing the relevant literature, the researchers noticed some shortcomings in the content of the music curriculum. They also noticed shortcomings in the instruments, resources, means and methods used in the music education process. These elements are used in the music educational process and environment. They aim at enhancing the learner's social interaction skills leading to establish effective social relationships that enable one to cope with the surrounding environment and get along with others. The researchers were able to identify these shortcoming due to the academic experience they possess. In addition, such shortcomings were identified because one of the researchers is specialized in playing Orff's music instruments.

The problem of the present study is represented in the following question:

(What is the extent of practicing the social interaction skills by Jordanian elementary school students in accordance with Carl Orff's approach to music education?)

\subsection{The Study's Objectives}

The present study aimed at identifying the extent of practicing the social interaction skills by Jordanian elementary school students in accordance with Carl Orff's approach to music education

\subsection{The Study's Significance}

The study's significance is represented in seeking to identify the role of music education in developing the social interaction skills of elementary school students in accordance with Carl Orff's approach to music education. The researchers chose this approach because it is considered as a comprehensive educational philosophy that might affect the social, physical, affective, and mental aspects of the learner's personality

\section{Definition of Terms}

\subsection{Social Interaction Processes}

They refer to the processes through which people communicate with each other mentally, emotionally, socially, culturally, physically, and spiritually leading to make each party satisfied about the other's behavior under 
general behavioral framework accepted by the group(Naser, 2004).

The procedural definition: They refer to the skills developed through allowing new relationships to develop with a group of members through specific music activities performed in music classes. Carrying out these processes requires having an understanding for several social value and standards. It also requires having awareness about the significance of participating in social activities to maintain these relationships stable and balanced

\subsection{Carl Orff's Approach}

It is an approach used for teaching children music. It depends much on singing, playing music, improvising, and moving (Yun and Kim, 2013).

\section{The Study's Limitations}

1- Thematic limits: The present study is limited to identifying the extent of practicing social interaction skills by Jordanian elementary school students in accordance with Carl Orff's approach to music education

2- Human limits: The present study is limited to all the male and female music teachers who teach at primary levels in public and private Jordanian schools

3- Spatial limit: The present study is limited to public and private Jordanian schools that are affiliated with directorates of education located at the northern, central, and southern regions of Jordan, provided that these schools include music teachers who teach at primary levels

4- Temporal dimension: The present study was conducted during the first semester of the academic year $2017 / 2018$

\subsection{The Study Methodology}

In order to fulfill the study's objectives, the researchers adopted the descriptive approach.

\subsection{The Study Population}

The study's population consists from all the male and female music teachers who were teaching at primary levels in public and private Jordanian schools during the year 2017 / 2018. According to the statistics of the Jordanian ministry of education, the study's population consists from 350 female and male teachers.

\subsection{The Study tool}

The researchers developed the study's questionnaire after reviewing the relevant previous studies. Such studies include: the studies conducted by Abu Ayash (2014), Yun and Kim (2013) and Jasem (2013). The study's questionnaire consists from one part that adopts the five point Likert scale. It aimed at exploring the actual practices of the social interaction skills by Jordanian elementary school students from the perspective of male and female music teachers who work at public and private Jordanian schools

\subsection{The Tool Validity}

In order to measure the content validity of the study's instrument, the researchers passed the instrument in its initial form to 15 experts to provide their comments. These experts are component university professors working at Jordanian universities and possess adequate experience. All of their comments were taken into consideration

\subsection{The Tool Reliability}

In order to measure the instrument's reliability, the researchers measured the internal consistency of each item of the questionnaire's items which are50 items. That was done through calculating the values of Cronbach's alpha coefficient for each item. The total value of Cronbach's alpha coefficient is 0.95 .

\section{Results and Discussion}

The study question is the following: What is the extent of practicing social interaction skills by Jordanian elementary school students from the perspective of female and male music teachers?

In order to provide an answer to this question, the researchers calculated the arithmetic means and standard deviations for the respondents' attitudes towards the extent of practicing the social interaction skills by Jordanian elementary school students. Table (1) below presents these arithmetic means and standard deviations. 
Table 1. The arithmetic means and standard deviations for the respondents' attitudes towards the extent of practicing the social interaction skills by Jordanian elementary school students in the descending order

\begin{tabular}{|c|c|c|c|c|c|}
\hline Rank & No. & Statement & $\begin{array}{l}\text { Arithmetic } \\
\text { means }\end{array}$ & $\begin{array}{l}\text { Standard } \\
\text { deviations }\end{array}$ & Level \\
\hline 1 & 33 & $\begin{array}{l}\text { There is mutual respect among students while they are performing } \\
\text { their tasks that are part of the music activity }\end{array}$ & 2.69 & 0.782 & Moderate \\
\hline 2 & 49 & Students perform activities that involve popular folk music & 2.68 & 0.677 & Moderate \\
\hline 3 & 11 & $\begin{array}{l}\text { Students perform physical movements in a way that is in } \\
\text { agreement with the music }\end{array}$ & 2.65 & 0.774 & Moderate \\
\hline 4 & 20 & $\begin{array}{l}\text { Students perform simple music patterns that are based on } \\
\text { repetition }\end{array}$ & 2.61 & 0.901 & Moderate \\
\hline 5 & 28 & $\begin{array}{l}\text { Students recognize their roles easily when performing different } \\
\text { group music activities }\end{array}$ & 2.52 & 0.738 & Moderate \\
\hline 6 & 12 & $\begin{array}{l}\text { The organized physical movements help students to (think and } \\
\text { act) in the same intended manner. That shall increase the } \\
\text { effectiveness of the social relationships between them }\end{array}$ & 2.50 & 0.789 & Moderate \\
\hline 7 & 34 & $\begin{array}{l}\text { Mutual influence between students shall ensure the continuation } \\
\text { of forming music groups }\end{array}$ & 2.46 & 0.773 & Moderate \\
\hline 8 & 50 & $\begin{array}{l}\text { Folk music activities promote interaction between the students } \\
\text { and their culture because such activities represent one of the } \\
\text { cultural elements }\end{array}$ & 2.44 & 0.751 & Moderate \\
\hline 9 & 21 & $\begin{array}{l}\text { The repetition method in the music education process promotes } \\
\text { the application of the participatory approach among the member } \\
\text { group }\end{array}$ & 2.43 & 0.892 & Moderate \\
\hline 10 & 30 & $\begin{array}{l}\text { Recognizing and predicting one's role by one's self shall make } \\
\text { the group balanced }\end{array}$ & 2.36 & 0.761 & Moderate \\
\hline 11 & 29 & $\begin{array}{l}\text { Students predict their roles easily while performing different } \\
\text { group music activities }\end{array}$ & 2.22 & 0.822 & Low \\
\hline 12 & 3 & Students practice music activities that unleash their own potentials & 2.14 & 0.885 & Low \\
\hline 13 & 5 & $\begin{array}{l}\text { Students practice music activities that simulate their social } \\
\text { environment which increase their social interaction }\end{array}$ & 2.12 & 0.845 & Low \\
\hline 14 & 9 & $\begin{array}{l}\text { Students use their bodies as a percussion instrument while } \\
\text { performing different kinds of music activities }\end{array}$ & 2.09 & 0.731 & Low \\
\hline 15 & 10 & $\begin{array}{l}\text { Physical movement encourages one to express his ideas and } \\
\text { feelings which promote his social interaction with each other }\end{array}$ & 1.99 & 0.795 & Low \\
\hline 16 & 45 & $\begin{array}{l}\text { Students sing songs that have a rhythm and deliver social ideas } \\
\text { and values }\end{array}$ & 1.96 & 0.782 & Low \\
\hline 16 & 43 & $\begin{array}{l}\text { Through the music education process, students act in a } \\
\text { cooperative context }\end{array}$ & 1.96 & 0.937 & Low \\
\hline 18 & 4 & $\begin{array}{l}\text { Providing students' potentials with attention shall participate in } \\
\text { unleashing these potentials }\end{array}$ & 1.93 & 0.966 & Low \\
\hline 19 & 35 & $\begin{array}{l}\text { Students sing songs of simple words that simulate their } \\
\text { environments which makes it easy for them to memorize }\end{array}$ & 1.92 & 0.834 & Low \\
\hline 20 & 6 & $\begin{array}{l}\text { Through social interaction, the students learn the social standards } \\
\text { that should govern his behavioral patterns and comply with them }\end{array}$ & 1.85 & 0.930 & Low \\
\hline 21 & 16 & $\begin{array}{l}\text { Students practice music activities that are in agreement with their } \\
\text { developmental characteristics }\end{array}$ & 1.79 & 0.917 & Low \\
\hline 22 & 1 & Students express their music-related orientations freely & 1.74 & 0.948 & Low \\
\hline 23 & 46 & $\begin{array}{l}\text { The songs that have a rhythm and carry social aspects participate } \\
\text { in increasing students' social discipline. That is because such } \\
\text { songs are considered one of the socialization methods }\end{array}$ & 1.73 & 0.877 & Low \\
\hline 24 & 13 & $\begin{array}{l}\text { Students perform expressive physical gestures, while listening to } \\
\text { systematic audio configuration }\end{array}$ & 1.69 & 0.805 & Low \\
\hline 24 & 44 & $\begin{array}{l}\text { The integration of the music activities shall promote the } \\
\text { application of a participatory approach among the group members } \\
\text { in relation to the division and distribution of roles }\end{array}$ & 1.69 & 0.975 & Low \\
\hline
\end{tabular}




\begin{tabular}{|c|c|c|c|c|c|}
\hline Rank & No. & Statement & $\begin{array}{l}\text { Arithmetic } \\
\text { means }\end{array}$ & $\begin{array}{l}\text { Standard } \\
\text { deviations }\end{array}$ & Level \\
\hline 26 & 36 & $\begin{array}{l}\text { Performing songs of simple words participates in promoting the } \\
\text { development of all the personality's aspects. That is because such } \\
\text { songs are considered learning models }\end{array}$ & 1.66 & 0.884 & Low \\
\hline 26 & 2 & $\begin{array}{l}\text { Providing students' music-related orientations with attention shall } \\
\text { participate in unleashing the potentials of those students }\end{array}$ & 1.66 & 0.928 & Low \\
\hline 28 & 15 & $\begin{array}{l}\text { The systematic sound effects facilitate the performance of the } \\
\text { music role and engaging in it }\end{array}$ & 1.64 & 0.901 & Low \\
\hline 29 & 17 & $\begin{array}{l}\text { Providing the students 'developmental characteristics with } \\
\text { attention shall promote the effective application of the } \\
\text { participatory approach among them }\end{array}$ & 1.62 & 0.917 & Low \\
\hline 30 & 14 & $\begin{array}{l}\text { The systematic sound effects participate in fulfilling the students' } \\
\text { (psychological and social) needs }\end{array}$ & 1.61 & 0.853 & Low \\
\hline 31 & 7 & $\begin{array}{l}\text { Students practice group music activities that are based on the } \\
\text { principle of organized play }\end{array}$ & 1.51 & 0.809 & Low \\
\hline 32 & 39 & $\begin{array}{l}\text { Students apply the flexibility principle while learning music } \\
\text { through responding effectively }\end{array}$ & 1.49 & 0.873 & Low \\
\hline 33 & 8 & $\begin{array}{l}\text { Organized playing participates in promoting a social } \\
\text { responsibility sense among students }\end{array}$ & 1.47 & 0.864 & Low \\
\hline 34 & 25 & $\begin{array}{l}\text { Practicing creative dramatics activities that represent the plot of a } \\
\text { story lying within the rhythm-based song - shall promote } \\
\text { interaction between the students and their culture. That is because } \\
\text { practicing such activities shall make students simulate group of } \\
\text { social values that are dominant within the society }\end{array}$ & 1.45 & 0.863 & Low \\
\hline 34 & 40 & $\begin{array}{l}\text { The flexibility-based music education participates in developing } \\
\text { the self-expression skills }\end{array}$ & 1.45 & 0.845 & Low \\
\hline 36 & 27 & $\begin{array}{l}\text { Using simple percussion instruments shall participate in } \\
\text { promoting interaction between the students from one hand and the } \\
\text { audio configuration and its hidden messages from another hand }\end{array}$ & 1.42 & 1.129 & Low \\
\hline 36 & 23 & $\begin{array}{l}\text { The music activities that involve rhythm-based song carrying a } \\
\text { story within participate in increasing students' motivation to learn }\end{array}$ & 1.42 & 0.847 & Low \\
\hline 38 & 22 & Students practice music activities that are based on story telling & 1.41 & 0.794 & Low \\
\hline 39 & 41 & $\begin{array}{l}\text { Students learn music through perception-based experiences which } \\
\text { increases their interaction }\end{array}$ & 1.40 & 0.872 & Low \\
\hline 40 & 24 & $\begin{array}{l}\text { Students practice creative dramatics activities representing the } \\
\text { plot of the story lying within the rhythm-based song }\end{array}$ & 1.39 & 0.801 & Low \\
\hline 40 & 32 & $\begin{array}{l}\text { Creativity-based education participates in increasing one's } \\
\text { self-esteem }\end{array}$ & 1.39 & 0.861 & Low \\
\hline 42 & 42 & $\begin{array}{l}\text { Learning through perception-based experiences shall develop } \\
\text { students' capabilities to produce sounds, and configure them in } \\
\text { a systematic manner }\end{array}$ & 1.38 & 0.856 & Low \\
\hline 42 & 18 & $\begin{array}{l}\text { Students practice music education activities that are based on the } \\
\text { simulation principle }\end{array}$ & 1.38 & 0.800 & Low \\
\hline 44 & 31 & $\begin{array}{l}\text { Students use their creative imagination in music activities which } \\
\text { promotes their interaction }\end{array}$ & 1.36 & 0.782 & Low \\
\hline 44 & 26 & $\begin{array}{l}\text { Students use simple tuned and unturned percussion instruments to } \\
\text { simulate the plot of the story lying within the rhythm-based song }\end{array}$ & 1.36 & 0.848 & Low \\
\hline 46 & 19 & $\begin{array}{l}\text { The application of the simulation principle promotes the } \\
\text { interaction between the students and their teacher which in turn } \\
\text { promotes the implementation of the dialogue style }\end{array}$ & 1.33 & 0.820 & Low \\
\hline 47 & 37 & $\begin{array}{l}\text { Students apply the creative play principle while performing music } \\
\text { activities which promotes their movement-based interaction }\end{array}$ & 1.32 & 0.758 & Low \\
\hline 48 & 47 & $\begin{array}{l}\text { Students are engaged in discovery-based learning activities which } \\
\text { increases their interaction }\end{array}$ & 1.31 & 0.847 & Low \\
\hline 49 & 48 & The discovery-based learning participates in enhancing the & 1.28 & 0.818 & Low \\
\hline
\end{tabular}




\begin{tabular}{|c|c|c|c|c|c|}
\hline Rank & No. & Statement & $\begin{array}{l}\text { Arithmetic } \\
\text { means }\end{array}$ & $\begin{array}{l}\text { Standard } \\
\text { deviations }\end{array}$ & Level \\
\hline \multirow{3}{*}{50} & \multirow{3}{*}{38} & educational process & & & \\
\hline & & $\begin{array}{l}\text { The movement-based interaction participates in stimulating } \\
\text { creativity leading students to improvise and discover things }\end{array}$ & 1.27 & 0.735 & Low \\
\hline & & Total & 1. 8025 & 0.71065 & Low \\
\hline
\end{tabular}

Based on table (1), it can be concluded that the overall level of practicing the social interaction skills by Jordanian elementary school students is low because the total mean is 1.80. As for the total standard deviation, it is 0.71 . The means of all the questionnaire statements are within the moderate and low levels. That can be attributed to the fact that music teachers face challenges and difficulties in the music education process. Such challenges and difficulties hinder those teachers from applying the educational strategies that fulfill the students' psychological, motor, mental, and social needs. Thus, that shall prevent the teachers from dealing with the social changes and fulfilling the modern-day requirements

The researchers present below a discussion for the statements that show the highest five means and the lowest five means:

Statement (33) shows a moderate mean of 2.69 which is ranked first. As for its standard deviation, it is 0.78 . The latter statement states the following: (There is mutual respect among students while they are performing their tasks that are part of the music activity). Such results is attributed to the fact that the nature of the performed music activities. This nature does not allow students to choose their music roles by themselves as they desire. For instance, students usually perform a specific task jointly under their teacher's directions. Thus, hat shall hinder the effective application of a participatory approach among the group members. In such a case, a mutual respect among students would appear to exist, but it is false. Such false respect is derived from adhering to their teacher's directions in the aim of achieving the best possible performance.

Statement (49) shows a moderate mean of 2.68 which is ranked second. As for its standard deviation, it is 0.68 . The latter statement states the following: (Students perform activities that involve popular folk music). Such results is attributed to the fact that students participate only in the music activities that are organized by the school in coordination with the ministry of education only. These activities are limited to competitions, and celebration of official events which require performing popular music activities. However, the latter music activities are not practiced as being educational models that are based on specific pedagogical foundations.

Statement (11) shows a moderate mean of 2.65 which is ranked third. As for its standard deviation, it is 0.77 . The latter statement states the following: (Students perform physical movements in a way that is in agreement with the music). This results is attributed to the students' low competency in understanding the rhythm. That can be attributed to the fact that students are not provided with opportunities to use their bodies as a percussion instrument through performing some physical movements while learning music. However, performing such movements shall promote their sense of rhythm. Them movements they often perform are limited to clapping at the beginning of some musical phrases of some specific music activities for enriching these music activities, rather than representing a rhythm.

Statement (20) shows a moderate mean of 2.61 which is ranked fourth. As for its standard deviation, it is 0.901 . The latter statement states the following: (Students perform simple music patterns that are based on repetition). This results is attributed to the fact that music teachers do not use the appropriate music educational methods that are based on repetition due to the non-availability of the required resources. Thus, that force these teachers to simplify, and divide the music information and patterns they want to teach and present them gradually through using various techniques.

Statement (28) shows a moderate mean of 2.52 which is ranked fourth. As for its standard deviation, it is 0.738 . The latter statement states the following: (Students recognize their roles easily when performing different group music activities). This results is attributed to the lack of diversity in the music activities that students perform. Such lack of diversity shall prevent the division and distribution of roles among students in accordance with their potential and inclinations. For instance, when music activities are limited to group singing, there won't be motivated to learn and respond effectively while performing music activities

Statement (26) shows a low mean of 1.36 which rank is 45 . As for its standard deviation, it is 0.848 . The latter statement states the following: (Students use simple tuned and unturned percussion instruments to simulate the plot of the story lying within the rhythm-based song). This results is attributed to the lack or scarcity of the 
simple percussion instruments. This result can be also attributed to the lack of experience among the music teachers in using the appropriate methods for directing students in using these instruments, in case they are available. This result can be also attributed to the absence of an appropriate educational environment for practicing such kind of activities within the classroom.

Statement (19) shows a low mean of 1.33 which rank is 16 . As for its standard deviation, it is 0.820 . The latter statement states the following: (The application of the simulation principle promotes the interaction between the students and their teacher which in turn promotes the implementation of the dialogue style). This results is attributed to the fact that students face difficulties in simulating their teacher's music performance when illustrating music idea to them. That is because these ideas are difficult to be understood and inconsistent with their environment, potentials and perception level. This results can be attributed to the non-availability of the required simple music instruments that allow students to perform simulation activities easily. That shall hinder the interaction between the students and their teacher which shall prevent any creative-based conversation that involves pleasure and thrill.

Statement (37) shows a low mean of 1.32 which rank is 47 . As for its standard deviation, it is 0.758 . The latter statement states the following: (Students apply the creative play principle while performing music activities which promotes their movement-based interaction). That is because students' roles are limited to performing formal music activities that don't require flexibility and often require one individual. Such role are performed though using musical instruments made for formal music. This result can be also attributed to the fact that students are not provided with opportunities to practice music activities that are based on the creative play principle. That is attributed to then on-availability of the musical instruments that suit the activities based on the creative play principle. Such music activities may include songs of simple words that deal with a subject related to their surrounding environment to make it easy to memorize. Such music activities may also include dancing melodies that encourage students to move. These activities may also include easy rhythm. This result can be also attributed to the non-availability of the appropriate musical instruments, and necessary means, instruments and resources within the school. It can be also attributed to the inappropriateness of the environment and using inappropriate educational methods and approaches by the music teachers

Statement (47) shows a low mean of 1.31 which rank is 48 . As for its standard deviation, it is 0.847 . The latter statement states the following: (Students are engaged in discovery-based learning activities which increases their interaction). That is because students learn music rules and the way of playing musical instruments through the traditional method which depends on their own personal efforts outside the school. In addition, music teachers usually train students how to perform specific music activities for fun rather than tutoring them. That shall eliminate the interaction between the students and their teacher which stems out from the discovery-based activities

Statement (48) shows a low mean of 1.28 which rank is 49 . As for its standard deviation, it is 0.818 . The latter statement states the following: (The discovery-based learning participates in enhancing the educational process). This result is attributed to the nature of the performed music activities. This nature does not provide students with opportunities to discover. To illustrate more, the music activities they perform often carry a formal nature which makes it difficult for students to improvise through composing their own simple music. However, it should be noted that such improvisation shall make students acquire social and personal skills

Statement (38) shows a low mean of 1.27 which rank is 50 . As for its standard deviation, it is 0.735 . The latter statement states the following: (The movement-based interaction participates in stimulating creativity leading students to improvise and discover things). That is attributed to the limited number of movements performed by students while performing music activities. Such limited number is attributed to the absence of motivation which should drive students to respond and interact with each other through moving and playing. The absence of this motivation shall deprive students from the opportunities to use their creative imagination in the learning process within an education environment governed by the principles of improvisation and flexibility

\section{Recommendations}

In the light of the aforementioned result, the researchers of the present study recommend the following

1) Promoting the role of the music education at private and public schools. The researchers also recommend providing all the necessary means and instruments for facilitating and improving the educational process

2) Holding more training courses for teachers regularly by the ministry of education about the music education strategies and methods 
3) Conducting more studies in the future about the implementation of global approaches to music education- such as: Kodaly approach - in the aim of developing students' social interaction skills.

\section{References}

Al-Hares, M. (2010). The effectiveness of a children singing program based on Carl Orff's approach on the development of emotional intelligence among a Jordanian sample, Unpublished $\mathrm{PhD}$ dissertation, The University of Jordan, Amman, Jordan.

Al-Lou, N. (2008). The most significant approaches to music education in the world (Episode 3). The Journal of Music Life, Damascus, 48, 209-228.

Al-Wahsh, M. (2014). The impact of music, drama, and structured playing in education, Amman, Dejla publishing and distribution house.

Eric, J. (2002). What research tells us about the brain Music Connection? Retrieved March 4, 2017, from http://www.edinak12m.hus/Lightants/Classes arise/Music20\%research.htm

Ezz, M. (2011). Art, music, and drama in children education, Amman, Al-Nahda publishing house.

Jasem, W. (2013). The impact of a music training program on the development of favorable social behaviors among the nursery children. The Educational Sciences Journal, Iraq(97), 300- 397.

Long, A. (2013). Involve Me: Using the Orff Approach within the Elementary Classroom. Eastern Illinois University, the Keep.

Naser, I. (2004). Socialization, Amma, Amman publishing and distribution house.

Sadeq, A. (2007). Studies and research about music psychologyand education, Cairo, Al-Anglo library. The references written in English language.

Webster, J. D. (2015). The Effects of Music Education on Academic, Social and Emotional Outcomes: An Investigation into the Perceptions of High School Students and their Parents. Unpublished Dissertation: Texas Weslyan University.

Yun, Y. B., \& Kim, J. E. (2013). The Effects of the Orff Approach on Self-Expression, Self -Efficacy. Social Skills of Children in Low-Income Families in South Korea, 92(4), 123-158.

\section{Copyrights}

Copyright for this article is retained by the author(s), with first publication rights granted to the journal.

This is an open-access article distributed under the terms and conditions of the Creative Commons Attribution license (http://creativecommons.org/licenses/by/4.0/). 